\section{Urban violence and public health in Latin America: a sociological explanatory framework}

\author{
Violencia urbana y salud pública en Latinoamérica: \\ un marco sociológico explicativo
}

\begin{abstract}
Interpersonal violence has become one of the main public health issues in Latin American cities. This article presents a framework for sociological interpretation that operates on three levels, expressed in the factors that originate, foment, or facilitate violence. Macro-social factors include: social inequality due to the increase in wealth versus poverty; the paradox of more schooling with fewer employment opportunities; increasing expectations and the impossibility of meeting them; changes in family structure; and loss of importance of religion in daily life. At the meso-social level the analysis highlights: increased density in poor areas and urban segregation; masculinity cult; and changes in the local drug market. The microsocial level includes: an increase in the number of firearms; alcohol consumption; and difficulties in verbal expression of feelings. The article concludes with an analysis of how violence is leading to the breakdown not only of urban life but also of citizenship as a whole in Latin America.
\end{abstract}

Violence; Sociology; Urban Health; Citizenship
Roberto Briceño-León 1

Latin American cities have become the stage for a silent and undeclared war. According to the World Health Organization (WHO), there are some 140,000 homicides a year in Latin America 1. Most of these deaths occur in cities and result from interpersonal violence, not wars or armed conflicts. They represent everyday violence, in which people meet death on their own street corners.

For several decades, Latin American families, institutions, and governments have made enormous efforts to improve the population's health conditions, from prenatal care and immunization to hospital care. As a result of such efforts, life expectancy in Latin America increased from 50 to 70 years in the second half of the 20th century. Meanwhile, an entire generation of parents moved to the cities in pursuit of a better future with greater possibilities for citizenship and better quality of life built on citizens' rights. These same parents raised their families in the cities and offered them care and education. They thus watched their children grow healthier, stronger, taller, and with more years of schooling than themselves, and full of aspirations, only to see them murdered.

What has happened to the cities of Latin America, the home to hopes and dreams, that they have become a threat to the majority of their inhabitants? 


\section{Accelerated urbanization}

Latin America has witnessed a process of breakneck urbanization, with people not only living in cities, but in increasingly larger cities, and this has meant a major change in daily living and public health conditions. In 1950 fewer than one-half $(41.0 \%)$ of the population lived in the cities, but by 2000 the figure had increased to three-fourths of the total population. The absolute figures are even more impressive: while in 1950 the total urban population of Latin America and the Caribbean was 69 million, by 2000 it had increased to 391 million, that is, 332 million more people in the cities. In 1950, the urban population was 40 million in South America, 15 million in Central America, and 6 million in the Caribbean. Fifty years later there were 228 million more in South America, 76 million more in Central America, and 18 million more in the Caribbean (Population Reference Bureau. World Population Data Sheet. Washington DC; 2004). The figures are overwhelming (Table 1).

In 1950, Buenos Aires had slightly more than 5 million inhabitants, and the other large Argentine cities combined had fewer than 3 million. In Brazil, São Paulo had 2.4 million and Rio de Janeiro 2.8 million. Mexico City had 2.8 million. In fifty years the urban population increased by more than twofold (Buenos Aries, 12.5 million), threefold (Rio de Janeiro, 10.4 million), six-fold (Mexico City, 18 million), or seven-fold (São Paulo, 17.7 million). In 1950 there was only one city with more than 5 million inhabitants, but by 2000 there were seven, because in addition to the ones mentioned above (Buenos Aires, Rio de Janeiro, Mexico City, and São Paulo), other cities had past the five million mark: Santiago, Chile (5.5 million), Bogotá, Colombia (6.2 million), and Lima, Peru (7.4 million). Combined, these seven cities were home to 78 million people 2 .

Table 1

Urban population of the Americas, 1950-2000.

\begin{tabular}{|c|c|c|c|c|}
\hline & \multicolumn{2}{|c|}{1950} & \multicolumn{2}{|c|}{2000} \\
\hline & Million & $\%$ & Million & $\%$ \\
\hline South America & 48 & 42.8 & 279 & 79.8 \\
\hline Caribbean & 6 & 35.4 & 24 & 63.0 \\
\hline Central America & 15 & 39.8 & 91 & 67.2 \\
\hline North America & 110 & 63.9 & 239 & 77.2 \\
\hline
\end{tabular}

Source: United Nations 2.
At the dawn of the 21 st century, $60.0 \%$ of the population live in cities with more than twenty thousand inhabitants, and half of these $60.0 \%$ (that is, one out of three Latin Americans) live in the 50 cities with a million or more inhabitants each 2,3 . The main problem of violence in Latin America is located in these 50 cities.

\section{Increasing violence}

According to the WHO 1 , there are 520,000 homicides a year worldwide, or 8.8 murders per 100,000 inhabitants, in addition to some 310,000 deaths classified as wartime casualties, or 5.2 per 100,000 inhabitants. Homicides are definitely a serious public health problem, surpassing that of war, as seen from these data.

In the WHO regions, the highest homicide rate per 100,000 is in Africa (22), followed by the Americas with 19 and Europe with 81.

Even so, the 19 per 100,000 homicide rate in the Americas is an average that conceals huge differences in the region: first, between the wealthy countries (the United States and Canada) and Latin America, and then among the Latin American and Caribbean countries themselves. The United States and Canada have a completely distinct social and economic reality and must thus be seen as separate from the other countries of the Americas (even though the differences between the two countries is large, since the United States has a historical homicide rate of 8 per 100,000, several times higher than Canada, with fewer than 2 per 100,000). The homicide rate in the United States is also higher than that of several Latin American countries, including Chile and Costa Rica.

Secondly, there are major differences between Latin American countries themselves, which we propose to classify in four groups, as follows: 1) fewer than 10 homicides per 100,000 inhabitants: Argentina, Chile, Uruguay, and Paraguay; 2) 11 to 20 homicides per 100,000 inhabitants: Peru, Nicaragua, Ecuador, Dominican Republic, Panama, and Honduras; 3) extensive violence, with 21 to 30 homicides per 100,000: Brazil, Mexico, and Venezuela; and 4) extremely high homicide rates, which for methodological reasons are classified as more than 31 per 100 thousand inhabitants, but which in practice can reach much higher levels: Colombia and El Salvador 4.

Table 2 shows the extremes, with low homicide rates in countries located in the Southern Cone of the continent, plus some Central American countries including Costa Rica. These countries have had homicide rates between 3 
Classification of Latin American countries by intensity of violence (2000).

\begin{tabular}{lll}
\hline Level of violence & $\begin{array}{l}\text { Homicide rate } \\
\text { (per 100,000 inhabitants) }\end{array}$ & Countries \\
\hline Low & Fewer than 10 & Argentina, Chile, Costa Rica, Uruguay, Paraguay \\
Medium & 11 to 20 & $\begin{array}{l}\text { Peru, Nicaragua, Ecuador, Dominican Republic, } \\
\text { Panama, Honduras }\end{array}$ \\
High & 21 to 30 & $\begin{array}{l}\text { Brazil, Mexico, Venezuela } \\
\text { Colombia, El Salvador }\end{array}$ \\
Very high & More than 31 &
\end{tabular}

Source: WHO 1, PAHO 102

and 5 per 100,000, and while they experienced an important increase in the 1990s (such as in Uruguay, where homicides doubled), the levels are quite low in comparison to the other Latin American countries.

At the other extreme, with high violence, are countries with intense social and political conflicts and which have suffered from war, such as El Salvador (from 1979 to the signing of the Chapultepec Agreement in 1992) or Colombia, where an armed conflict is still raging between four factions disputing for control of the territory: two guerrilla forces, one paramilitary, and the country's official army. The homicide rates can exceed 60 or 100 per 100,000 inhabitants. Still, most homicides in Colombia are not the direct consequence of warfare, but of daily violence. However it is impossible to determine how many of the victims are the secondary effect of wartime situation in El Salvador 5 or of covert or low-profile military action in Colombia. Colombia also has the most kidnappings in the world, estimated in 2004 at more than three thousand persons in captivity. Many kidnappings end in the victim's death, and such actions are a combination of guerrilla warfare and common crime, often difficult to differentiate 6,7 .

Between the two extremes are the other countries. Brazil, Mexico, and Venezuela have experienced an increasing wave of violence and homicides. There are no armed political conflicts, so the violence is "routine" and associated either with common crime and drug trafficking or emotional conflicts in which hatred and pain culminates in the use of firearms.

Such violence is primarily urban: in 1997 São Paulo and Rio de Janeiro had an average of 600 homicides per month 8 . Homicide rates in some cities can more than double the national average: for example, Rio de Janeiro with 102, San Salvador 139, and Caracas 52. In Cali, Colombia, where an effort to reduce violence has frequent- ly been cited as successful, a homicide rate of 91/ 100,000 persisted from 2002 to 2004 9,10,11,12,13.

Some pockets of rural violence exist, but they are few. The Latin American rural population has remained stable at around 128 million, and rural poverty (while more dramatic) has not increased as rapidly as urban poverty 14 . Traditional rural violence and some political conflicts continue in peasant areas, including the guerrilla warfare in Colombia and Mexico, but the number of homicides they produce is insignificant as compared to deaths in cities.

\section{Cities of law, cities of fear}

Cities should be the locus for rights and safety, for life rather than death. Citizens as bearers of rights originated in the city, and for centuries people saw the city as a refuge against the insecurity of the countryside, as well as a source of rights. Greek tradition made a synonym of the citizen as a person with the right to live in the city and the right to decide the political future. To be citizen requires both living in the city and having rights to participate in political life.

The city was the place for exchange (the market), but also for order and norms. Weights and measures regulating relations between buyers and sellers were created in the city. But the city was also a place of domination, since much of the order had to be imposed, and this meant forcing submission.

The city was the place of safety: people were controlled, areas were lit, and the police protected the citizenry. Citizenship originated in the city, in the connection between equals, subject to the law, not to others.

The city was also the place of civility: good manners, courtesy and hypocrisy, all that was called urbanity 15,16 .

Latin American cities represented the refuge of an elite that had (and exercised) rights, but 
from which the vast majority of the rural population was excluded, subject to semi-feudal working conditions and political and social power, often controlled by private armies enforcing their lords' authoritarian and personalized will. This was the history of the rural "bosses" or "colonels", where the law was enforced with little impartiality. Migration to the city represented the dream not only for a better material life, but also a life with rights, where one could live under the rule of law, not in submission to individual power.

Despite multiple urban problems in countries like Colombia, thousands of persons have moved from rural areas to the cities, fleeing the arbitrary rule and the horrors of guerrilla and paramilitary violence. These "displaced" persons as they are called in Colombia total nearly three million who have abandoned their homes and belongings to seek refuge in the large cities, where they expect peace, security, and rule of law.

Latin America cites were a place of hope for security and law, hence the great rural-to-urban exodus in the 1940s and 50s.

However, beginning in the 1980s, violence changed significantly, and homicide rates doubled in most countries 17,18 . Worldwide, the estimated homicide rate (per 100,000) increased from 5.47 in 1975-1979 to 8.86 in 1990-1994 19. In Venezuela, it increased from 8 in the early 1980s to nearly 25 by the mid-1990s 20. In Mexico, in the early 1980 s the homicide rate was 10.2/100,000, and by 1995 it had reached 19.6 (an increase of 90.0\%) 21,22,23,24. In Colombia the rate increased from $20-40$ per 100,000 in the 1970 s to $70-90$ in the 1990 s 25 . There was an increase in all Latin American countries, regardless of the previous conditions (slightly or highly violent).

This situation led to a feeling of great insecurity in the cities 26,27 . Fear is distributed on a more egalitarian basis than that of the population's real security, because the role of the mass media, vicarious victimization, and rumor lead to similar feelings in victimized and non-victimized groups 28,29,30. Fear displays a subjective sensation, but that has practical consequences because people act as if it were true 31 . In a multi-center study sponsored by PAHO in 1996, a group of questions addressed the sense of insecurity that persons felt in different areas of the city: home, street, and public transportation. The results (Table 3 ) showed a strong sense of insecurity in the city centers, including Madrid, which was used as a control for comparisons because of its low crime rate. In order of importance, the fear of becoming a victim of violence in public transportation was next. In Bahia, Brazil, people felt the greatest insecurity in public transportation, but in nearly all Latin American cities buses have become a trap where passengers and drivers can easily be assaulted while the vehicle is in movement. The most routine acts become a source of fear and threat.

Cities are no longer the source of security once dreamed of. Mothers of tens of thousands of youths murdered every year and the fearful inhabitants of cities ask themselves the same question: why has violence increased so much in the last twenty years?

\section{A sociological framework for explaining urban violence}

To understand violence, we present a set of hypotheses on the different dimensions of the phenomenon. However, since variables of a different order are concerned, we have grouped them into a sociological model we developed under the Social Sciences Laboratory (LACSO) to provide an explanation for current violence in Latin America. This framework is not intend-

Table 3

Feeling of insecurity (somewhat insecure, very insecure) in different areas of the city, 1996/1997.

\begin{tabular}{lccccc}
\hline & $\begin{array}{c}\text { Bahia, } \\
\text { Brazil (\%) }\end{array}$ & $\begin{array}{c}\text { Caracas, } \\
\text { Venezuela (\%) }\end{array}$ & $\begin{array}{c}\text { San Jose, } \\
\text { Costa Rica (\%) }\end{array}$ & $\begin{array}{c}\text { Santiago, } \\
\text { Chile (\%) }\end{array}$ & $\begin{array}{c}\text { Madrid, } \\
\text { Spain (\%) }\end{array}$ \\
\hline At home or in apartment & 64.5 & 74.8 & 11.4 & 12.0 & 4.7 \\
On street, daytime & - & 74.6 & 29.0 & 18.3 & 12.1 \\
On street at night & - & 83.9 & 51.0 & 41.6 & 47.7 \\
In public transportation & 91.9 & 89.3 & 45.3 & 65.7 & 37.1 \\
In city center & - & 91.1 & 81.3 & 71.3 & 47.2 \\
\hline
\end{tabular}

Source: Activa Survey, PAHO, LACSO (Social Sciences Laboratory). 
ed to be exhaustive. Rather, it situates the social and psychosocial conditions that we consider relevant for comprehensive sociology, thereby differentiating it from explanatory proposals that are individual per se, such as the Bandura theory of aggression 32,33, ecological theories 34 , economic theories 25 , and of course classical criminology 35 and the theory of deviation 36,37 , even while recognizing their contribution and sharing some aspects with all of them.

The current proposal is not a model for universal explanations, because we believe it is impossible to interpret violence in the same way for ancient Greece, World War II, crimes committed by stilted lovers, or serial murders 38,39. Each of these phenomena requires a unique explanation, because science can offer only conjectures on specific matters that will never be universal 40,41 .

The sociological framework seeks to work with various spheres of social life: 1) the situational, which refers both to general conditions of society and specific circumstances, such as physical circumstances in the environment and social circumstance of other actors, which are imposed on the individual as binding references at the time decisions are made; and 2) the cultural, which is external to the situation, precedes it in time, and is imposed on individuals in social learning and marks the way they interpret signals sent to them by the situation (the medium or the other actors) and how they may decide their course of action $42,43,44$.

The purpose of this framework is to formulate hypotheses 45 on the two above-mentioned dimensions of the social (i.e., situational and cultural) so that as hypotheses of truth they allow one to understand 46 what takes place in a specific social reality. And since we are optimists, this framework may allow us to propose an appropriate intervention.

The framework has three dimensions, representing three distinct levels of explanation (Figure 1), as follows:

1) The structural level refers to a social process of a macro nature and with a genesis and persistence over a longer period of time. At this level we refer to factors that originate violence, since their structural character has an inevitable imprint on society as a whole, giving it a generalized and diffuse effect. It is thus not easy to identify immediate associations with variables at this level, but it determines a transformation in society that creates the basis for violent behavior but does not determine what necessarily occurs. Due to their characteristics, these circumstances are the most difficult to change, but perhaps for this very reason they are the most relevant as first causes.

2) The second level contains meso-social aspects, with less structural roots and thus representing the area where the situation and culture have a more immediate effect on behavior.

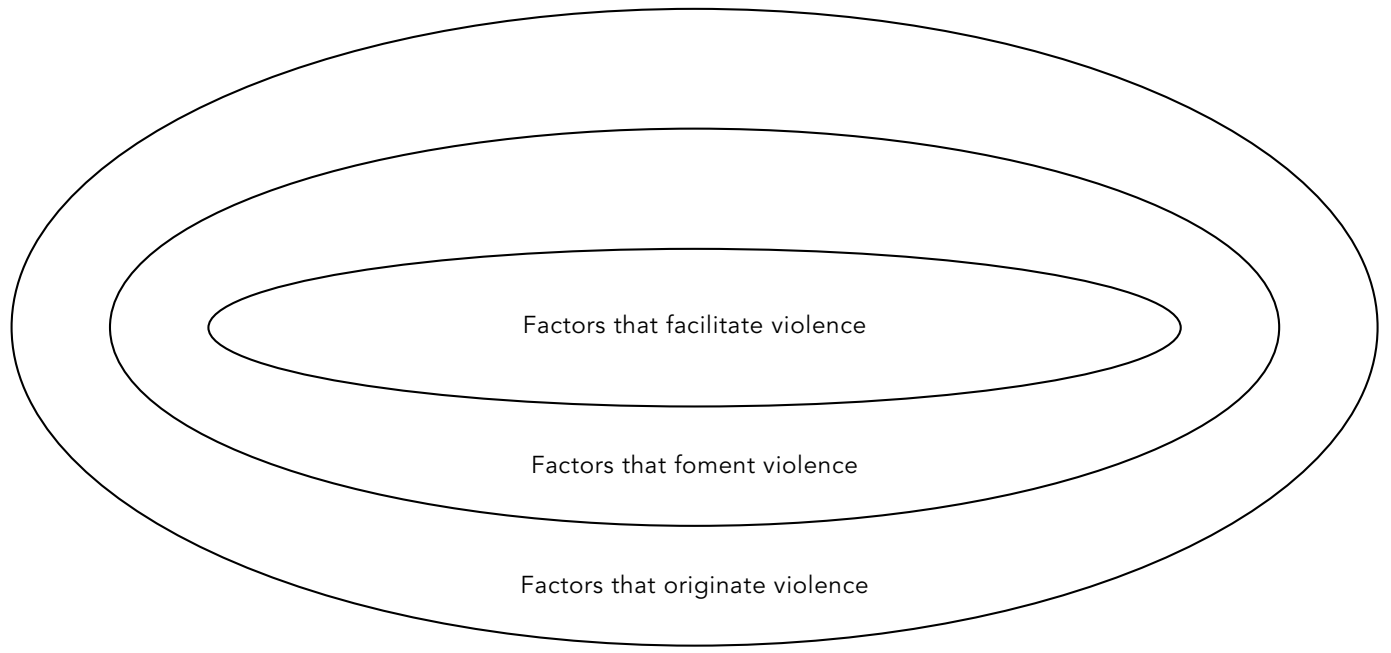


At this level we thus refer to factors that foment violence. Factors at this level may encourage and facilitate violence, but modifying this level is simpler than the previous one. The level of freedom of individuals in relation to these factors is much greater than in the previous case.

3) The third level includes micro-social factors which we also call facilitators because they have a more individual nature and cannot be considered causes, but rather accompanying factors and facilitators for the passage to the violent act or as responsible for an action's lethalness. The connections here are more immediate and the associations are easier to establish, but they also indicate more association than causality.

\section{The macro-social level: factors that originate violence}

At the macro-social level we postulate five types of factors. Two are of a situational nature: increased urban inequality and increased education and unemployment. Two others are of a contingent nature, namely increased aspirations and the impossibility of satisfying them, and changes in family structure. One is cultural, namely the decreasing capacity of the Catholic Church to exert social control.

The city has both more wealth and more poverty

In Latin America, the distance between the poor and the rich is the greatest in the world. On other continents, such as Africa, there is more poverty, but there is also not as much wealth. In Europe, on the other hand, there is more wealth but not as much poverty. What is unique in Latin America is the presence of both components: more poverty and more wealth. There is thus more inequality than if everyone were rich or poor.

When data on distribution of wealth between the poorest and the wealthiest groups in the developed countries and Latin America are reviewed (Table 4 ), the portion that the poor detain is quite similar, while that detained by the wealthiest $10.0 \%$ in Latin America is much greater than what the same group detains in the developed countries. Inequality is determined by what the wealthiest detain, not the poorest. And this is true in all Latin American countries. Of course there are differences between the countries. In Brazil, the wealthiest $10.0 \%$ detain $45.0 \%$ of the wealth, as compared to $27.3 \%$ in Uruguay; but although the percentage is lower in Uruguay, it is still very high. Moreover, in all Latin American countries the poorest $10.0 \%$ detain less than $2.0 \%$ of the wealth 47,48 .

This situation has changed over time, but unfortunately not for the better, based on either the extreme polarization of income (the poorest $1.0 \%$ and the wealthiest $1.0 \%$ ) or the poorest and wealthiest $25.0 \%$. Londoño \& Szekely 49 calculated the income distribution ratio between the wealthiest fourth $(25.0 \%)$ and the poorest fourth using the Lorenz curve and found important modifications. In 1970 the ratio was 22.9 , but there was an improvement in the income distribution during that decade that led to a decline in the ratio by 1982 (when it was 18.0). From then on the situation of inequality deteriorated, pushing the ratio back to the same level in 1990 as 20 years earlier (22.9), after which it worsened until reaching 24.4 in 1995. In 1970 , the average income of the poorest $1.0 \%$ of the population was US\$112, reaching US\$159 in 1995. That is, the poor improved their real income as measured in 1985 dollars. But during the same period, the wealthiest $1.0 \%$ increased their average income from US\$40,711 to US\$66,363. The income of the $1 \%$ wealthiest in 1970 was 363 times that of the poorest $1.0 \%$, but in 1995 the ratio had risen to 417 . What changed was not poverty, but inequality.

Many of the changes in violence can be related to transformations in Latin America. The 1980s were marked not only by stagnation, but also by greater inequality, reflected both in people's living standards and fundamentally as an increase in urban poverty 50 . While in rural areas there was a greater percentage of moderate and extreme poverty than in the cities $(62.0 \%$ vs. $38.0 \%$ and $38.0 \%$ vs. $13.5 \%$, respectively), this did not represent major changes because between 1980 and 2002 the percentages did not increase as much in the countryside as in the cities, nor was the increase in the absolute number of persons as great as in the cities, because the rural population remained relatively stable during this period.

As shown in Table 5, the percentage of the poor or indigent population increased from 1980 to 1990 and then dropped until 2002 for all rural and urban groups. Nevertheless, in 1980 there were 73 million poor in the rural areas, increasing to 74.8 million in 2002 , that is, two million more poor in the countryside. Meanwhile, in the cities there were 136 million poor in 1980 and 221 million in 2002, or 85 million new poor in the cities. The same was true for extreme poverty, with increased by 6 million in the countryside and 29 million in the cities 51 . 
The important points in relation to violence are urban poverty and indigence, due to the magnitudes they involve and because unemployment is a particularly urban issue. Unemployment is low in rural areas, where people can always participate in farming. As Table 6 shows, there is an important difference between three groups of Latin American countries in terms of poverty, urbanization, and violence. In groups 1 and 3, violence as measured by the homicide rate is low, but the factors producing this situation are different in the two cases.

In the first group, we contend, there is little violence because of a low poverty level and high urbanization. The exception is Costa Rica, which is not highly urban but is unique in Central America since it has had some singular social control mechanisms and is the only Latin America country that eliminated its army several decades ago.

The third group has Latin America's highest poverty levels, but the poverty is rural because these countries have low urbanization. Honduras, with the most poverty among the countries in this group, has less than half of its population living in cities.

We thus hypothesize that violence is concentrated in the countries of Table 6 where there is high poverty and high urbanization, that is, with urban poverty. An exception is Argentina, with a low homicide rate 52 . Historically, Argentina has had low poverty and a large middle class, but the data in the chart reflect the country's crisis, with a 132 billion dollar debt and recession since 1998, reaching its peak with the freeze on savings deposits, protests by the middle class on December 20, 2001, and the suspension of year-end bonuses. We believe the violence in Argentina will tend to appear increasingly like that of Brazil or Mexico rather than Chile, and we thus chose to keep Argenti- na in this group. There is no reliable information on homicides in Guatemala or Bolivia.

\section{More education, less employment}

Cities have offered greater access to education for broad segments of the Latin American population. Education in the rural areas has always been difficult, both because of child labor in agriculture and the scarcity of (and distance to) schools. In urban areas, education has been different and despite numerous multiple limitations, by the end of the $20^{\text {th }}$ century $86.0 \%$ of youth ages 15 to 29 years had managed to conclude their primary studies while $26.0 \%$ from 20 to 24 years of age had completed secondary education.

However, this improvement in education has not represented better opportunities for young people to obtain employment or rise socially. According to the International Labor Organization 53 , the unemployment rate among youth worldwide is two to three times that of adults. In Latin America, the unemployment rate among adults dropped in the late 1990s, and in 2003 it was estimated at $6.7 \%$. Among youth the situation was quite different, since it increased to $15.7 \%$ (more than double that of adults) by that same year.

This youth unemployment has some singularities, behaving like a Gaussian curve, but in-

Table 4

Distribution of wealth in Latin America and the developed countries.

\begin{tabular}{lcc} 
& Latin America (\%) & Developed countries (\%) \\
\hline Wealthiest 10\% & 48.0 & 29.0 \\
Poorest 10\% & 1.6 & 2.5 \\
\hline
\end{tabular}

Source: Ferranti et al. 47

Latin America: moderate and extreme poverty in urban and rural areas.

\begin{tabular}{|c|c|c|c|c|c|c|c|c|}
\hline & \multicolumn{4}{|c|}{ Moderate poverty } & \multicolumn{4}{|c|}{ Extreme poverty } \\
\hline & \multicolumn{2}{|c|}{ Urban } & \multicolumn{2}{|c|}{ Rural } & \multicolumn{2}{|c|}{ Urban } & \multicolumn{2}{|c|}{ Rural } \\
\hline & million & $\%$ & million & $\%$ & million & $\%$ & million & $\%$ \\
\hline 1980 & 135.9 & 29.8 & 73.0 & 59.9 & 22.5 & 10.6 & 39.9 & 32.7 \\
\hline 1990 & 200.2 & 41.4 & 78.5 & 65.4 & 45.0 & 15.3 & 48.4 & 40.4 \\
\hline 2002 & 221.4 & 38.4 & 74.8 & 61.8 & 51.6 & 13.5 & 45.8 & 37.9 \\
\hline Increase 1980/2002 & 85.5 & 8.6 & 1.8 & 1.9 & 29.1 & 2.9 & 5.9 & 5.2 \\
\hline
\end{tabular}

Source: Assembled from Economic Commission for Latin America and the Caribbean 51, charts I.2 and I.3. 
Latin America: households in situation of poverty, urban population, and homicides.

\begin{tabular}{|c|c|c|c|c|}
\hline Level of violence & Countries & $\begin{array}{l}\text { Poverty rate } \\
\text { (households) }\end{array}$ & $\begin{array}{c}\text { Urban } \\
\text { population (\%) }\end{array}$ & $\begin{array}{c}\text { Homicide rates } \\
\text { per } 100,000\end{array}$ \\
\hline \multirow[t]{3}{*}{ Group 1: low } & Uruguay & 9.3 & 93.0 & 4.4 \\
\hline & Chile & 15.4 & 87.0 & 5.4 \\
\hline & Costa Rica & 18.6 & 59.0 & 9.3 \\
\hline \multirow[t]{8}{*}{ Group 2: high or very high } & Brazil & 29.9 & 81.0 & 23.0 \\
\hline & Argentina & 31.6 & 89.0 & 9.9 \\
\hline & Mexico & 31.8 & 75.0 & 19.6 \\
\hline & Peru & 42.3 & 72.0 & 11.5 \\
\hline & Ecuador & 42.6 & 61.0 & 15.3 \\
\hline & El Salvador & 42.9 & 58.0 & 55.6 \\
\hline & Venezuela & 43.3 & 87.0 & 35.0 \\
\hline & Colombia & 48.7 & 71.0 & 61.6 \\
\hline \multirow[t]{5}{*}{ Group 3: low } & Paraguay & 52.0 & 54.0 & 12.6 \\
\hline & Guatemala & 52.3 & 39.0 & - \\
\hline & Bolivia & 55.5 & 63.0 & - \\
\hline & Nicaragua & 62.9 & 58.0 & 8.4 \\
\hline & Honduras & 70.9 & 47.0 & 9.4 \\
\hline
\end{tabular}

Source: Assembled from WHO 1, Londoño \& Guerrero 10, Buvinic et al. 19, Fundación Mexicana de la Salud 21, Population Reference Bureau 103, Economic Commission for Latin America and the Caribbean 51, Instituto Apoyo 104, Lederman 105.

Data on poverty Peru 1999; Brazil, El Salvador, Paraguay, and Nicaragua 2001; Chile 2003

other countries 2002. Data on population from 2000. Homicide data from 1994 to 1999.

verted, that is, with greater employment opportunities for groups with either very little or a lot of education: for those with more schooling because they are more skilled and reached the university, and for those with less schooling because they live in the countryside (where there is less unemployment as a social category) or are employed in heavy labor with low wages, which individuals with some education tend to refuse. Meanwhile, the group from 15 to 24 years of age and with seven to twelve years of schooling suffers the highest unemployment rate in the region. It is also the group that both suffers from and perpetrates more violence.

An estimated 565 young people (10-29 years) are murdered per day worldwide. In $2000,199,000$ young people died of violence, with a homicide rate of $9.2 / 100,000$. Latin America has a major share in that figure. The overall world rate varies greatly among regions, because there is less than 1 homicide per 100,000 in Europe, 11 per 100,000 in the United States, 17.6 per 100,000 in Africa, and 34.6 per 100,000 in Latin America. Juvenile violence is clearly a Latin American problem. The highest rates in the world occur in Latin America: Co- lombia with 84.4, El Salvador with 50.2, Brazil 32.5, Venezuela 25, and Mexico 15.3 homicides per 100,000 1,54,55,56.

Violence is a youth issue. An estimated $28.7 \%$ of all homicide victims in Latin America are from 10 to 19 years of age (Inter-American Development Bank. Youth Violence Prevention. Technical Note 10. Washington DC; 2002). Why is this age group affected so heavily? There are several reasons, but we emphasize the difficult age of adolescence, complicated by social conditions. People used to be classified in three ages: childhood, adulthood, and old age. Adolescence did not exist. Only recently has this category designated a moment of change in the individual's biology, but also to represent changing roles assigned to the adolescent by society. Adolescents are neither children nor adults. They have the physical conditions to work, but laws prohibit them from doing so until adulthood; they have the physical conditions for reproduction but are prohibited from exercising their sexuality. Presumably they must study until they reach working age, but they either have no schools or are expelled from the educational system. Imprecise, inadequate social insertion of adolescents is one an 
important source of violence, with the incapacity to make the prescribed and proscribed roles coincide.

Juvenile violence begins at a prime moment in adolescence at around 13 years of age, when youth begin demonstrating the pretensions of being adults but limited social capacity to behave as such. At around 13, boys begin to take interest in women, but young girls of the same age are more interested in adult men, and younger girls are still children. At this age they begin having problems with their schoolwork, in the 7 th or 8 th grades, and many drop out of school, but they are not of age and lack technical skills to work. This is a group of youth who do not study or work and who are at great risk of getting trapped in violence.

As shown in Table 7, 12.0\% of all Latin American youth have no work and are not attending school. And what can young people from 15 to 18 years of age do if they are not working or studying? The vast majority do not live in wellto-do families that can support them and supply them with resources to meet their needs. Although this is scarcely one-tenth of the population, there are some 58 million poor Latin American young people, 21 million in extreme poverty. Even if one assumed that $90.0 \%$ are male saints with extremely positive value socialization and never tempted by evil, 10.0\% of youth are still at risk of crime. At best, this percentage represents 580,000 poor youth or 210,000 youth in extreme poverty and susceptible to crime and violence, more than the current Latin America prison population.

\section{More aspirations, but less capacity} to meet them

Youth outside the labor market and school system do not have fewer expectations or dreams than others. Their aspirations are the same as those of other young people who are in school and have good incomes, because the mass culture transmits the same ambitions.
During the 1940s, the sociology of modernization emphasized the "revolution of expectations". According to this theory, when rural Latin Americans living in a traditional society made contact with the city and modernity, they were bound to change their expectations and dream of a better life, represented by greater and better consumption, and the fetters on society would be broken and social forces would awaken in a development "take-off" 57.

The process actually occurred in Latin America. The rural exodus changed the expectations of millions, placing them on equal ground with the rest of society in terms of expectations. Paradoxically, the same society denied them the means to satisfy these expectations. Latin America shows an asymmetry between aspirations and the capacity to satisfy them. We are terribly equal in our desires and frightfully unequal in our actual possibilities to achieve them.

The first generation that reached the cities realized a major share of their dreams: access to hospitals, schools nearby for their children, electricity, refrigerators, and TV sets. They had nothing of the kind in the countryside, and this was an important change in their lives. Yet their children were born in a world that already had hospitals, schools, refrigerators, and TV sets. For the new generation, these achievements mean nothing. The children were born into a world where mass culture imposed new and often more superficial consumer goals. A young person from a middle-class family, preparing to enter the university, and an unemployed youth from a poor family have the same tastes and the same aspirations. Urbanization and television democratized expectations. In 1980 there were $98 \mathrm{TV}$ sets for every thousand Latin Americans, and by 1997 the number of TV sets had doubled, at 205 per thousand (UNESCO. Radio and Television Receivers. Toronto: Institute of Statistics; 1999). But the latest Nike or Reebok shoes advertised on TV are out of reach for youth from the favela in Rio de Janeiro, the

Table 7

Latin America: youth employment and school enrollment.

\begin{tabular}{lccccc}
\hline & $\begin{array}{c}\text { Works and } \\
\text { studies (\%) }\end{array}$ & Only works (\%) & Only studies (\%) $\begin{array}{c}\text { Does not work } \\
\text { or study (\%) }\end{array}$ & $\begin{array}{c}\text { Domestic } \\
\text { activities (\%) }\end{array}$ \\
\hline Males & 52.7 & 10.9 & 22.2 & 12.3 & 1.9 \\
Females & 28.3 & 7.8 & 24.3 & 14.1 & 25.6 \\
\hline
\end{tabular}

Source: Assembled from Economic Commission for Latin America and the Caribbean 51. 
comuna in Medellín, or the colonia in Mexico City. The 150 dollars that some brand name shoes cost are more than most young Latin Americans earn in a month.

Youth have problems not only finding employment; when they to get jobs they earn less than adults. According to the International Labor Organization $53,93.0 \%$ of the jobs available to young people in the world are in the informal sector, where they earn $44.0 \%$ of what they would earn in the formal sector. According to the Economic Commission for Latin America and the Caribbean 51, the average income of young people (15-19 years) is one-third that of adults, and those from 20 to 24 years of age earn a little more than half that of adults.

This asymmetry between expectations and achievements raises a classic sociological drama 58 , because as the means prescribed by society (employment, effort, and savings) do not allow achieving the ends, many youth take the proscribed routes of violence as a means to seize what they cannot attain formally 59,60,61,62. A youth who sells drugs in Caracas said proudly during an interview in a juvenile detention center that he earns on a single Friday night more than his neighbors do carrying packages for a month. And he added petulantly that he was not born to be poor, because as the Mexican song says, he likes the good life ("Yo no nací pa' pobre, me gusta todo lo bueno...”).

\section{Less social control by the family}

One of the greatest forces for containing violence is the family, because it incorporates the person into a world governed by norms and with limits. The family teaches children the difference between what is permitted and prohibited, initiates them in regard to rewards and punishments, and introduces them (starting with the first rule of prohibition of incest) in the symbolic pact that is the law 63,64. The family's influence is as much original and past as situational and present. Past because it is the basis for the formation of the individual and present because it is the context of close social interaction that can regulate and modulate behavior. Changes in the Latin American family thus have an important impact on the violent individual conduct.

The family has lost force in its two functions of social control because of the transformations it has experienced in recent decades. As shown in Table 8, the traditional family, in which the father works and the mother stays home in charge of the housework and caring for the children, decreased by $10.0 \%$ in the 1990s. The change is not only because women who have finished school and want a satisfying professional career with financial independence leave home to work, but also because the man's income drop has forced wives to seek a second income for the household. Under such conditions, socialization and social control of children have been seriously jeopardized, especially because urban life has limited the presence of the grandparents in many families, and children are thus left alone for long periods of the day.

In addition, as shown in Table 8 , there are more single-parent households as a result of broken relations, whether because of more divorces in legally constituted couples (as in all Latin American countries) or due to the dissolution or non-consolidation of common law marriages. In 2002, 16.0\% of Latin American families were headed by women, and $37.0 \%$ of these were poor. The percentage varies among countries. In Colombia, $46.0 \%$ of single-parent families headed by women are poor, $48.0 \%$ in Ecuador, $44.0 \%$ in Argentina, 32.0\% in Brazil, and $27.0 \%$ in Mexico. For every three singleparent families, two have a father or a mother who leaves home to work, so if these families have no grandmother or other relative available to care for the children, the latter are left alone at home or on the streets and in many cases under the care of an "older" sister who (as we have observed many times) is rarely more than 10 years old but is already responsible for cooking meals and caring for her younger siblings.

This precarious social control by the family has multiple consequences. One of the most immediate is to place youth in the street at the disposition of professional criminals. Families have little power to control criminal or violent acts by youth. We asked a 17-year-old (who was in jail in Caracas for robbery and two murders) what his mother said when he began giving her money two years earlier: "At first she asked me where I got it, but later she didn't say anything. What was she going to do? She needed the money. Other times she cried, but she took it".

\section{Less force of religion}

Religions have always been an important instrument for regulating individual behavior. The Fifth Commandment of the Old Testament is an irrefutable test: "Though shall not kill" is an explicit order. How many such orders are obeyed (even by the most religious) is a matter of time and the moment, that is, of the history in which decisions are made and norms ap- 
plied, since even the Vatican instituted capital punishment.

In Latin America, the Catholic religion has lost considerable capacity to affect daily individual lives. Religion remains, and at least $70.0 \%$ of the population is still Catholic and follows the fundamental rites of human existence: baptism, religious marriage, and death rites. But little can be said of its impact on the daily behavior of persons beyond the broad guidelines over life. The story is quite different with Protestants, including Evangelists, who have experienced major growth throughout the region, since they exert great control over individual behavior: daily worship and Bible reading, tithing, and bans on alcohol and tobacco consumption, vulgar language, and violent behavior. The types of control and level of compliance vary from one denomination to another and from one country to the next, but they generally wield more force than the Catholic Church.

In the Activa survey sponsored by PAHO in seven Latin American cities, we attempted to identify a correlation between type of religion and violent attitudes, and the only significant association was found in Rio de Janeiro, where Protestants manifested a stronger rejection of violence than Catholics. In Caracas, non-Catholic Christians rejected extra-judicial police activity more than Catholics, and the non-religious were those who significantly approved of it 65 . Church attendance functioned, because those who worshipped regularly were less violent than those who never did. A recent study by LACSO in Caracas used the "data mining" technique to analyze data from a survey on violent attitudes in 2004 and showed that the main distinguishing factor was religion, i.e., whether the individual practiced a religion (regardless of which one).

When we asked violent youths about religion and if they considered their actions "sinful", they responded resignedly that they were. Yet religious morals and real action appear to be two distinct registries. To kill someone is not good, but it is done, and the justifications vary. One powerful excuse is self-defense and the belief that if they do not kill others, they themselves are condemned to die. For many, religion no longer inhibits violence, but has not been replaced by lay morals, which could be supported by the rule of law to dissuade homicidal behavior.
Table 8

Types of urban nuclear families.

\begin{tabular}{lrr}
\hline Type of family & $\mathbf{1 9 9 0}$ & $\mathbf{2 0 0 2}$ \\
\hline Two-parent family & & \\
Spouse does not work & 46.2 & 36.2 \\
Spouse works & 27.0 & 32.9 \\
Total two-parent & 73.2 & 69.1 \\
& & \\
Single-parent family & 8.0 & 10.3 \\
Female head who works & 5.4 & 5.7 \\
Female head who does not work & 2.1 & 2.5 \\
Male head & 15.5 & 18.5 \\
Total single-parent & & \\
\hline
\end{tabular}

Source: Assembled from the Latin American and Caribbean Center for Demography 106

\section{Factors that foment violence}

Meso-social factors are a second group referring to specific situations that increase violence by fomenting a type of exacerbating behavior. There are three most important factors of this type. Two are situational: urban segregation, producing divided cities, and the local drug market. One is cultural: the masculinity cult.

\section{Segregation and urban density}

Latin American cities experienced slow growth during much of the early $20^{\text {th }}$ century, and their expansion added new territories to the edge of cities. Land on the urban outskirts was less valuable and lacked services. Urban workers and the recently arrived poor built their housing there, congregating people with less schooling and characterizing a type of social behavior known in many countries by the Spanish term orillero, a synonym for coarse, uncivilized behavior. Yet migration to the cities turned secondary growth of the outskirts into a key factor of urban life. Favelas in Brazil, comunas in Colombia, barrios in Venezuela, and pueblos jóvenes in Peru became essential urban components, sometimes larger than the formal city itself, although the urban authorities resisted recognizing them as such.

The presence of these new social groups occupying urban territory has been interpreted in various ways and with dissimilar theoretical frameworks, but all identify the union and separation between the formal and informal city, between the legal and illegal, the planned and the unplanned. In the mid-1950s some authors 
using the theory of modernization contended that these areas were a leftover from the rural countryside and a tradition that had been installed in the modern cities 57,66,67. Others, based on Marxist categories, felt that an "industrial reserve army" or a "relative super-population" lived on the outskirts 68,69. According to others, there were two urban circuits that functioned differently but were integrated at some points 70 . Still, all attempted to explain a phenomenon that still calls attention, since it was a novel urbanization process, different from that of Europe and not preceded or accompanied by the city's industrialization. It was urbanization without industrialization 71,72 . This meant that many new urban residents experienced difficulties finding employment and housing. Since society could not offer an answer, they found one themselves in the interstices of land ownership, a space that formal urbanization had overlooked and where they proceeded to build their homes. And they found work in what we now call the informal sector.

For several decades Latin American cities grew like this, and 30.0 to $80.0 \%$ of the urban population came to live this way. Urban inhabitants made great efforts to improve the city, as they tell in beautiful stories in all the countries 73. Until the 1980s, such growth always meant systematic consolidation of housing and the physical surroundings. Visitors may have been confused when they found precarious housing and classified it as deteriorated (as one school of North American sociology contended), but this was not true, because the conditions improved year by year; the makeshift walls and roofing were replaced with solid masonry walls and tile roofs, running water and electricity were installed, and streets and stairways were built. The time for this transformation varied from one country to another. In the 1960s the transformation of a house could take five years in Caracas and ten years in Lima. Family incomes in the cities were very different, but there was a general feeling of living better each day.

That situation changed. In the early 1970s, $36.0 \%$ of the Latin American urban population lived in poverty. This figure increased to $60.0 \%$ by the early 1990s, even though the urbanization rate had decelerated significantly. This increase in urban poverty has had three important impacts as factors for violence. First, houses that were continuously improving have begun to deteriorate, and the feeling of increasing improvement has been replaced by a bitter emotion of being increasingly worse off. This relates to the aging of the housing's physical structure, because after 30 or 40 years it requires mainte- nance that the inhabitants can scarcely afford because of their shrinking income. Second, the population density has increased in low-income areas due to natural demographic growth, because children and grandchildren of the original occupants continue to live on the same lots and the formerly empty spaces are now occupied (the backyard and the area between the house and the neighbors). When there is no more ground space, a second and up to seventh floor are built on the land originally occupied by a makeshift single-family dwelling 74 . In Caracas, in some low-income barrios (like Los Erasos), there is a higher density than in the area with the city's tallest residential buildings (Parque Central). From an ecological perspective, high density is a reason for permanent conflicts between people, both because of aggression that appears with many people and few effective norms for cohabitation, but also (and this is the third factor) because unplanned urban growth and subsequent densification produce tortuous territories that are easily controlled by criminal groups and refractory to efficient and secure action by the police 75 . A similar situation occurred in medieval cities, thus the large avenues and diagonals in Paris, built by Baron Haussman after the Revolt of the Commune for the Prussian army to be able to move and take control of the different areas, avoiding irregular alleys with spontaneous urbanization.

\section{The culture of masculinity}

Violence is a men's issue. Men both practice and suffer from it. Worldwide, the male homicide rate is three to five times that of women. Up to 14 years of age, there is no difference between the sexes, but from 15 (when conduct is defined by sex) up to 44 years of age the difference is abysmal, because the male rate is five times greater: 19 homicides per 100,000 inhabitants in males as compared to 4 per 100,000 in women 1 .

In Latin America the situation is even worse. In Colombia, El Salvador, and Venezuela, the probability of men being murdered is 12 times that of women, in Ecuador 11, and in Brazil 10. The situation is similar in countries with low homicide rates, like Chile and Costa Rica, where the probability is 6 times greater in men than women (Table 9).

Why is there such a marked difference between the sexes? We believe that there is a culture of masculinity that favors violent actions and exposure to the risk of violence. This culture exists, as in all relations defined by sex, as mark- 
ing difference in what is considered feminine culture vis-à-vis risk and violence. Men act in a way that differentiates them from women and thus become victims of violence $76,77,78$.

Female culture basically involves a conduct of avoidance. Women avoid conflict, fighting, and risk and do not care if they are labeled as afraid. This is important for men, because to avoid fighting and risk is equated with behaving like a woman, a dangerous situation for a 15-year-old in a male chauvinist culture, because it means losing face and becoming the object of ridicule and social discredit. Assuming a conduct stigmatized as feminine means to submit to other men.

The culture of masculinity acquires special dimensions during adolescence, when males seek the construction of their own identity. It is a difficult moment for males and females under any circumstances, but in relation to violence it is much worse for men, who are obliged to reaffirm themselves in a culture of masculinity that exposes them to risk 79 . The culture of "respect" as recognition of their identity and virility by their peers acquires much greater force at this time 80,81 . Respect is an important component of masculinity in different societies and ages, but among youths it is more relevant because of their own lack of identity. Becoming a man in a low-income context is hard for youth, and violence is a way of growing. The research thus showed the ostentatious exercise of violence as taken for granted among younger adolescents, before they are consolidated as outlaws respected on their turf. Once they are recognized as such and begin a stable sexual life with a partner, they reduce their excess violence and begin to administer it with a rationality in keeping with their goals 82,83 .

\section{The local drug market and impunity}

Drug use itself does not appear to be a major factor for violence, but the drug market is. Users may adopt violent behavior while under the influence, but this is not common. It tends to happen more frequently during prolonged abstinence by addicts or when they commit crimes to buy drugs, but not while they are under the influence 84 .

The main problem is the drug market and its transformation beginning in the 1980s. For some time the commercial arrangement between wholesalers and retailers was cash payment of a commission on the sale of a specific drug. A dealer sold a kilo and was paid a thousand dollars, for example. This situation changed in many places in the 1980s, and cash payment
Table 9

Latin America: homicide rates according to gender in selected countries.

\begin{tabular}{lrc}
\hline & Men & Women \\
\hline Colombia, 1995 & 116.8 & 9.0 \\
El Salvador, 1993 & 108.4 & 8.4 \\
Brazil, 1995 & 42.5 & 4.1 \\
Venezuela, 1994 & 29.7 & 2.3 \\
Mexico, 1997 & 29.6 & 3.1 \\
Ecuador, 1996 & 28.2 & 2.5 \\
Costa Rica, 1995 & 9.3 & 1.4 \\
Chile, 1994 & 5.4 & 0.8 \\
\hline
\end{tabular}

Source: Assembled from WHO 1.

was replaced by payment in kind, that is with drugs. The retailers earned more money, because the drugs received in payment were worth much more than the previous cash payment and wholesalers were now able to eliminate the problems with employee payments by converting them into businessmen through a kind of outsourcing.

The problem now shifted to the retailers, who had to sell more drugs to make a profit. There were two possibilities: either the regular customers bought more, or they expanded the market to include new buyers. This was not so simple, thus the easiest way to expand one's market was by eliminating other sellers. And this is the story of gang war, or the turf war to control local drug markets.

A study on homicides in 1995-1996 in Cali, Colombia 85 showed that $15.0 \%$ of homicides were connected to drug trafficking, but on observing the murders in detail the figure increased to $46.0 \%$, because it included 20 double homicides, 5 triple homicides, and one quadruple and one sextuple homicide in 1996, in addition to 14 victims of professional assassins.

This drug-related violence involves high levels of impunity. Punishment for homicide is rare in Latin America, but the connection to drugs has aggravated this reality and fomented the perception that drug crime goes unpunished. Drug earnings are so high that they have corrupted the police in various countries, but when something goes wrong with bribes or death threats, they have also controlled judiciary officials (judges and attorneys become victims of violence). And if something still goes wrong and traffickers go to jail, the drug lords provide them with protection and comfort in prison. In Latin American jails, where everything costs money, drug-related inmates have 
separate sections or special rooms, appliances, cell phones, and even bodyguards hired within the prison institution, which they can afford with money from the organization.

With prospects of such high earnings as those from the drug business and such limited risk of being arrested and punished, drugs become an alternative for many people and an important fomenter of violence in Latin America.

An even greater effect is the tremendous damage from drug business on penal institutions, which is not restricted to impunity for a specific trafficker, but rather the deterioration of the system's overall operation. The penal system requires institutions and an ideology that sustains it and legitimizes its sanctions. When fear and money grip officials, the crisis is not of this or that judge, but of the institution as a whole. A Colombian judge who was trying a drug case reported having received offers of millions to absolve a trafficker charged with several crimes, which he had systematically rejected. One day a gift arrived at his office. Fearing that it was a bomb, the security guards inspected the package carefully, found no obvious danger, and delivered it to the judge. The judge opened it to find a simple album of family photos: his daughter playing in the schoolyard, his son entering the movies with some friends, his wife shopping at the market... the message was clear and he understood it. With great regret and shame, he abandoned the case.

\section{Factors that facilitate violence}

There is a third kind of factor that is not the origin of violence and thus cannot be causally incriminated, but which facilitates violent behavior or makes it more damaging and more lethal, because it enables and stimulates such behavior. Such factors are not in the social structure, but in the individual.

\section{Increase in firearms among the population}

The world has witnessed a major increase in the possession of light firearms: revolvers, pistols, mini-machine guns. Firearms are not consumed while they are used, unlike many other individual or wartime products. Arms remain and are reused and resold in secondary or tertiary markets. Such arms produce more than 200,000 deaths every year in non-warlike events (in wars they add another 300,000 deaths) 86 .

More than one thousand companies produce firearms in 98 countries around the world, but $70.0 \%$ of the world market is supplied by
American and Russian companies. Firearms legislation varies greatly between countries, from the strictest prohibition in the United Kingdom to the most lenient in the United States, where bearing arms is a constitutional right. Although the existence of firearms in a society is not necessarily a direct efficient indicator of violence, it is true that the existence of firearms in the population facilitates lethal violence, because interpersonal conflict, street fights, and unrequited passion can end in blows or death, and the substantive difference can result from firearms, not the rage, hatred, or pain involved. The same hate can produce either a bruised face or a fatal victim. A study in 25 high-income countries showed that homicides suffered by women were significantly associated with the availability of firearms.

The availability of arms among citizens makes crime more violent because perpetrators know they may meet armed resistance and thus prepare themselves and act with greater violence than what they will presumably find with their victims. In societies without firearms, delinquents can dominate victims with knives or simply with physical force, because they know that others will not have weapons to defend themselves.

Latin America has the most firearms-related homicides in the world. Table 10 shows the world's regions and how Latin America triples the African homicide rate and quintuples the North American and Central and Eastern European rates, while it is a staggering 48 times higher than in Western Europe.

In Latin America, an estimated 45 to 89 million firearms are in the hands of civilians. Since the vast majority are illegal, there are no precise data, and the experts base these estimates on a lower and upper threshold and believe that there are 20 to 30 million in Brazil, 2.5 to 16.5 million in Mexico, 4 to 6 million in Argentina, 1.4 to 2 million in Chile, and 200,000 to 500,000 in Ecuador. Yet the lethalness of such firearms varies greatly between countries. In Ecuador, with fewer arms, more homicides are committed (one for every 150-380 available guns). In Chile, with many more arms, there is one homicide for every 17-24 firearms 87,88. Firearms are not directly responsible for violence, but under conditions of social and individual conflict they facilitate serious and mortal aggression.

\section{Alcohol consumption}

Excessive alcohol consumption is associated with violent behavior and casualties. The AC- 
TIVA study showed an association between victimization and consumption of more than five drinks per occasion several times a week. This association appeared in Rio de Janeiro, Caracas, San José de Costa Rica, and Madrid 89. Likewise, a study on violence in couples in Caracas showed that a factor associated with serious aggression between spouses was excessive alcohol consumption by one or both 90 .

Alcohol itself does not have to be a cause of violence, since (like other drugs) it can produce a sleepy and tranquilizing effect in some persons. But alcohol consumption also releases inhibitions and reduces barriers and repressions that culture has planted in the individual. Internalized norms and the Freudian superego are undermined by drinking, and people can become more expressive, more sincere, and more aggressive.

Many fights and homicides result from a banal but murderous combination of intoxication and possession of weapons. Banal, because many of the people (both men and women) we interviewed in jail reported that they would have avoided such acts if they had been able to consider the consequences of their actions. One of the most successful policies adopted in cities with high rates of violence has thus been a Dry Law decreed on what are considered critical dates. In Cali, Colombia, this prohibition was tested on days of important soccer matches, and it reduced the homicides involving elated (victorious) versus revolted (defeated) fans.

\section{The inability to verbally express feelings}

Finally, an individual circumstance that facilitates the passage to a violent act is the extreme difficulty some people experience in expressing their inner feelings of rage or disgust in words. Our hypothesis is that people who cannot communicate their outrage in words express it with acts such as slaps, kicks, fistfights, or use of weapons. Words can be a substitute for the violent act and in this sense are also violence, but with far fewer consequences and much less physical damage than violence itself. Violence is always an act of communication, a language perverted by feeling or ratified by functional reason. Words can exorcise rage and make others receive the aggression, but without physically injuring them 91 .

Some researchers of gender-related violence contend that verbal and physical violence must be equally condemned. From a moral perspective, one can agree and consider both incorrect (and even contend that words can occasionally cause more damage than a
Table 10

Estimates (low and high) of homicides involving firearms, by region.

\begin{tabular}{|c|c|c|}
\hline & \multicolumn{2}{|c|}{ Homicide rate per 100,000} \\
\hline & Low threshold & High threshold \\
\hline Africa & 3.83 & 5.90 \\
\hline Latin America and the Caribbean & 12.80 & 15.47 \\
\hline North America & 3.17 & 3.50 \\
\hline Middle East & 0.52 & 1.80 \\
\hline Central and Eastern Europe & 1.63 & 3.09 \\
\hline Western Europe & 0.32 & 0.35 \\
\hline Southeast Asia & 1.04 & 1.45 \\
\hline Asia and Pacific & 0.51 & 0.54 \\
\hline World Total & 2.85 & 3.96 \\
\hline
\end{tabular}

Source: Assembled from Small Arms Survey 86 .

slap). Silence and indifference can also hurt more than a slap. But in terms of the violence that damages the body or kills, words are a great help for conflict-resolution in the field of the symbolic.

The issue is why some people turn their impulses into acts while others do not. Why do some people say they really want to punch you, while others simply do it? There are two factors: the moral controls over the passage to the act, and the substitute realization of the desire. We have observed that some people who fail to construct the verbal substitution express their feelings and desires in the passage to the act. Psychoanalysis has worked through these substitute mechanisms. Dreams are one example, and Freud 92 thus wrote that healthy men dream what perverse men do. One could paraphrase Freud by saying that peaceful men say what violent men do.

The inverse association some researchers have found between more schooling and a decrease in violent behavior or serious victimization has various explanations. Education offers more opportunities for employment, and individuals incorporate more social norms. On the other hand, years of study provide more verbal skills and allow people to express feelings and manage conflicts through negotiation and agreement, i.e., with words rather than violence.

\section{City, citizenship, and violence}

These three levels of factors allow a multi-factorial approach to urban violence in Latin America whereby we can grasp both the particular aspects of the social structure of Latin 
America and its cities and the dynamics of people's behavior. People's action synthesizes the social determinants and singularities of individual freedom, which in the ultimate analysis always makes each event of daily violence unique and unrepeatable.

Each of these levels covers the next, encompasses it, and contributes to its comprehension. We should not be satisfied with overarching explanations that claim to solve the problem by attributing violence to neoliberalism. The social process leading to violence in Latin America is highly complex, and we must avoid simplifications, because the goal is not to reduce the phenomenon's multifaceted nature, but to formulate scientific hypotheses to transform a complex and incomprehensible phenomenon into one that is equally complex, but somewhat more comprehensible.

We can thus better comprehend the social transformations in violence in Latin America and their public health consequences. The impact on the population's health relates not only to the alarming figures on mortality presented here or in the scarcely reliable statistics on morbidity, with thousands of wounded and maimed (indeed, we have not even taken issue with such statistics). The impact also deals with the millions of indirect victims who share the pain of their relatives, neighbors, and friends, and the population at large, living a terrified life, in which the city and citizens' rights lose out 93,94 .

The fear of becoming a victim of violence produces different responses by members of society. There is both an increase in private security and a demand for greater public crackdown on crime. Enhanced private security seeks to reduce individual risk exposure and create conditions to avoid being victimized, by limiting going out in public or circulating in certain parts of the city or at certain times, increasing security in the home, privatizing public spaces, and increasing private protection. The demand for cracking down on violence (often referred to as the "war on crime") calls for greater police presence on the streets and in public areas, more aggressive treatment of delinquents by the police, including support for extra-judicial police actions (e.g., arrest without warrant and even torture and summary executions), and more severe punishment 65,95,96,97,98,99.

The city is transformed to adapt reactively to insecurity. The divided city tends to reinforce (intentionally or not) the segregation of territories occupied by different social groups. The middle class begins closing off streets in its neighborhoods and hiring private guards. Then the poor do the same with pedestrian walkways, and since they can not afford private police, they exercise vigilance on their own. The street as an open air market is increasingly replaced by shopping centers, with private boulevards and security, because they have few doors and private security systems. Shopping centers began as a luxury for the middle class, but have gradually become the favorite place for all social strata. Not only have malls been created for low-income strata, but all shopping centers have become the favorite place for social outings by the urban poor. One of the key reasons is security.

Violence represents a loss for both the city and citizenship (social rights represented by the modern city as both illusion and reality). Violence is a permanent threat to the most fundamental right, i.e., the right to live. The city used to be the place for a more protected life, but the urban environment has become a threat. The right to free circulation is curtailed when streets are closed off and people abandon many areas of the city because they fear being victimized. People have the right to a secure home, but families of all social strata feel unsafe even in their own homes. The middle class places fences, electrical wiring, and alarms, and the poor build their houses without windows to protect themselves. The house becomes a refuge where people isolate and enclose themselves as a defense. The city also represents the right to work and recreation, and workers now refuse to work overtime at night (which could provide additional income) and stop going to parties because they fear coming home late at night. Violence also threatens the same rights, because fear and distress induce many citizens to support extra-judicial action that violates individual human rights (including but not limited to those of delinquents). People on the street ask why society should defend the human rights of outlaws. What about the human rights of law-abiding citizens? All of this represents a terrible loss of citizenship.

Achieving peace and overcoming violence means making cities a place of freedom and citizenship. The city should be the place of inclusion, where different and unequal people meet. The city is a space for negotiation between diverse individuals and groups. A homogeneous city is bland and boring. Large cities (Rome, Istanbul, Paris, and New York) have always been meeting places for diverse social groups, ideologies, and religions. Although on a more modest scale, the world's cities of today tend to repeat a pattern that increases with globalization 100,101. Cities are places for agree- 
ment and cohabitation among the unequal. Although we have no reason to claim equal living conditions, exclusion need not exist either. Cities are the place to include everyone in equal citizens' rights, with the possibility of achieving a decent and healthy urban life, without either ostentatious wealth or dire poverty. Cities are the place to generate agreements requiring progress in social life and social rights, where the unequal can meet (whether on a friendly or conflictive basis) and mutually advance the construction of an urban space, since cities are the privileged place for individual rights and collective cohabitation.

\section{Resumen}

La violencia interpersonal se ha convertido en uno de los principales problemas de salud pública de las ciudades de América Latina. El artículo presenta una interpretación sociológica de la violencia en tres niveles: (a) macro-sociales - la desigualdad social debida al incremento de la riqueza y la pobreza; la paradoja del mayor nivel educativo de las personas, pero las menores oportunidades de empleo, el incremento de las expectativas y de la imposibilidad de satisfacerlas; los cambios en la familia y la pérdida de importancia de la religión en la vida cotidiana de las personas; (b) meso-sociales - el incremento de la densidad en las zonas pobres y la segregación urbana, la cultura de la masculinidad y los cambios en el mercado local de la droga; (c) micro-sociales - el incremento de las armas de fuego, el consumo de alcohol y las dificultades de expresión verbal de los sentimientos por las personas. El artículo concluye con un análisis sobre cómo la violencia está llevando no sólo a la pérdida de las ciudades, sino a la ciudadanía en América Latina.

Violencia; Sociología; Salud Urbana; Ciudadanía
There is an old German saying, "Stad Luft mach frei": the air of the city makes you free. The expression originated in medieval times, when a serf who succeeded in proving that he had lived in the city for a year and a day was entitled to his freedom and the right to remain in the metropolis. Latin American cities will only reclaim the widespread dream of freedom they represented in the $20^{\text {th }}$ century if they succeed in overcoming the epidemic of violence. Thus, cities need social transformations that grant more freedom rather than restricting it. Healthy cities that aspire to public health must also be safe cities.

\section{References}

1. World Health Organization. World report on violence and health. Geneva: World Health Organization; 2004.

2. United Nations. World population prospects. The 1999 revision. New York: Population Division, United Nations; 2001.

3. United Nations. The state of world population. New York: United Nations; 2004.

4. Briceño-León R. La nueva violencia urbana en América Latina. In: Briceño-León R, editor. Violencia, sociedad y justicia en América Latina. Buenos Aires: Consejo Latinoamericano de Ciencias Sociales; 2002. p. 13-26.

5. Cruz JM. Violencia, democracia y cultura política. Nueva Sociedad 2000; 167:132-46.

6. Franco S. El quinto: no matar. Contextos explicativos de la violencia en Colombia. Santafé de Bogotá: TM Editores; 1999.

7. Camacho A, Guzmán A. Ciudad y violencia. Revista Foro 1990; (12):22-32.

8. Pinheiro PS. Violência, crime e sistemas policiais em países de novas democracias. Tempo Social Revista de Sociologia da USP 1997; 9:43-52.

9. Instituto de Estudos da Religião/Banco Interamericano de Desenvolvimento. Magnitude, custos econômico e políticas de controle da violência. Washington DC: Banco Interamericano de Desenvolvimento; 1997. 
10. Londoño JL, Guerero R. Violencia en América Latina. Epidemiología y costos. Washington DC: Banco Interamericano de Desarrollo; 1999. (Documento de Trabajo R-375).

11. Souza ER. Homicídios no Brasil: o grande vilão de saúde pública na década de 80. Cad Saúde Pública 1994; 10 Suppl 1:45-60.

12. Reichenheim ME, Werneck GL. Anos potenciais de vida perdidos no Rio de Janeiro, 1990. As mortes violentas em questão. Cad Saúde Pública 1994; 10 Suppl 1:188-98.

13. Guerrero R. Epidemiología de la violencia: el caso Cali, Colombia. In: Banco Interamericano de Desarrollo, editor. Hacia un enfoque integrado del desarrollo: ética, violencia y seguridad ciudadana. Washington DC: Banco Interamericano de Desarrollo; 1996.

14. Baker J, Schuler N. Analyzing urban poverty: a summary of methods and approaches. Washington DC: World Bank; 2004. (World Bank Policy Research Working Paper 3399).

15. Elias N. El proceso de la civilización, investigaciones sociogenéticas y psicogenéticas. México DF: Fondo de Cultura Económica; 1987.

16. Remy J, Voye L. Ville, ordre et violence. Espace et liberté. Paris: Presses Universitaires de France; 1981.

17. Del Olmo R. Ciudades duras y violencia urbana. Nueva Sociedad 2000; 167:74-86.

18. Rotker S. Ciudades escritas por la violencia (A modo de introducción) In: Rotker S, editor. Ciudadanías del miedo. Caracas: Nueva Sociedad; 2000. p. 7-22.

19. Buvinic M, Morrison A, Shifter M. La violencia en América Latina y el Caribe. Un marco de referencia para la acción. Washington DC: Banco Interamericano de Desarrollo; 2000.

20. Pérez-Perdomo R. Contar los cuerpos, lamer las heridas: la tarea de cuantificar la violencia delictiva. In: Briceño-León R, Pérez-Perdomo R, editores. Morir en Caracas. Violencia y ciudadanía en Venezuela. Caracas: Facultad de Ciencias Jurídicas y Políticas, Universidad Central de Venezuela; 2002.

21. Fundación Mexicana de la Salud. Tendencias y causas de delito violento en el Distrito Federal. Informe final. México DF: Fundación Mexicana de la Salud; 1999.

22. Lozano R. La violencia en ciudad de México: análisis de la magnitud y su repercusión económica. México DF: Centro de Economía y Salud, Fundación Mexicana para la Salud; 1997.

23. Lozano R, Hijar M, Zurita B, Hernández P, Avila L, Bravo ML, et al. Capital lesionada: violencia en ciudad de México. In: Londoño JL, Gaviria A, Guerrero R, editores. Asalto al desarrollo: violencia en América Latina. Washington DC: Banco Interamericano del Desarrollo; 2000. p. 205-32.

24. Hernádez-Bringas $H$. Las muertes violentas en México. México DF: Universidad México Americana del Norte; 1989.

25. Rubio M. Crimen e impunidad. Precisiones sobre la violencia. Bogotá: TM Editores; 1999.

26. Martín-Barbero J. La ciudad entre medios y miedos. In: Rotker S, editor. Ciudadanías del miedo. Caracas: Nueva Sociedad; 2000. p. 29-35.

27. Pegoraro J. Violencia delictiva, inseguridad urbana. La construcción social de la inseguridad ciudadana. Nueva Sociedad 2000; 167:114-32.

28. Ferraro KF. Fear of crime. Interpreting victimization risk. New York: State University of New York; 1995.

29. Cisneros A, Zubillaga V. La violencia desde la perspectiva de la víctima: la construcción social del miedo. Espacio Abierto 1997; 6:71-97.

30. Navarro JC, Pérez-Perdomo R. Seguridad personal un asalto al tema. Caracas: Ediciones Instituto de Estudios Superiores de Administración; 1991.

31. Soarez LE. O inominável, nosso medo. In: Violência e política no Rio de Janeiro. Rio de Janeiro: Relume Dumará/Instituto de Estudos da Religião; 1996. p. 59-64.

32. Bandura A. Aggression: a social learning theory. Englewood: Prentice-Hall; 1973.

33. Bandura A. Social foundations of thought and action. A social cognitive theory. New Jersey: Prentice Hall; 1986.

34. Moser C, Shrader E. Crimen, violencia y pobreza urbana en América Latina: hacia un marco de referencia integrado. Washington DC: World Bank; 1998.

35. Cerqueira D, Lobão W. Determinantes de criminalidades: arcabouços teóricos e resultados empíricos. Dados 2004; 47:233-69.

36. Carranza E, editor. Delito y seguridad de los habitantes. México DF: Siglo XXI Editores; 1997.

37. Reiss Jr. JA, Roth A. Understanding and preventing violence. Washington DC: National Academies Press; 1993.

38. Arendt H. On violence. San Diego: Harcourt Brace \& Company; 1970.

39. Wievorka M. Violence en France. Paris: Seuil; 1999.

40. Popper K. La lógica de la investigación científica. Madrid: Editorial Tecnos; 1977.

41. Boudon R. La logique du social. Paris: Les Èditions Hachette Litérature; 1979.

42. Briceño-León R. Buscando explicaciones a la violencia. Espacio Abierto 1997; 6:45-69.

43. Minayo MC. Relaciones entre procesos sociales, violencia y calidad de vida. Ciênc Saúde Coletiva 2005; 1:69-78.

44. Ferrel J. Cultural criminology. Annu Rev Sociol 1999; 25:395-418.

45. Popper KR. Conjectures and refutations. The growth of scientific knowledge. London: Routledge/Kegan Paul; 1972.

46. Weber M. Economía y sociedad. México DF: Fondo de Cultura Económica; 1977.

47. Ferranti D, Perry G, Ferreira FHG, Walton M. Inequality in Latin America \& Caribbean. Breaking with History? Washington DC: World Bank; 2004.

48. Gasparini L. Income inequality in Latin America and the Caribbean: evidence from household surveys. La Plata: Centro de Estudios Distributivos, Laborales y Sociales; 2003. (Documento de Trabajo 2).

49. Londoño JL, Szekely M. Persistent poverty and excess inequality: Latin America, 1970-1995. Washington DC: Inter American Development Bank; 1997. (Working Paper 357).

50. Fassin D. Exclusion, underclass, marginalidad. Figures contemporaines de la pauvreté urbaine en France, aux Etats-Unis et en Amerique Latine. Rev Fr Sociol 1996; 37:37-75. 
51. Comisión Económica para América Latina y el Caribe. Panorama social de América Latina. Santiago de Chile: Comisión Económica para América Latina y el Caribe; 2004.

52. Spinelli H, Alazraqui M, Macías G. Muertes violentas en la Ciudad Autónoma de Buenos Aires. Una mirada desde el sector salud. Buenos Aires: Organización Panamericana de la Salud; 2005.

53. Internacional Labor Organization. Información sobre el empleo de los jóvenes. Geneva: Internacional Labor Organization; 2004.

54. Organización Panamericana de la Salud. Taller sobre la violencia de los adolescentes y las pandillas ("Maras") juveniles. San Salvador: Organización Panamericana de la Salud/Organización Mundial de la Salud; 1997.

55. Yunes J, Rajs D. Tendencia de la mortalidad por causas violentas en la población general y entre los adolescentes y jóvenes de la región de las Américas. Cad Saúde Pública 1994; 10 Suppl 1:88125.

56. Londoño JL, Gaviria A, Guerrero R. Asalto al desarrollo. Violencia en América Latina. Washington DC: Banco Interamericano de Desarrollo; 2000.

57. Germani G. Política y sociedad en una época de transición. Buenos Aires: Paidós; 1961.

58. Merton RK. Teoría y estructura social. México DF: Fondo de Cultura Económica; 1965.

59. Cruz JM, Portillo-Peña N. Solidaridad y violencia en las pandillas del Gran Salvador. Más allá de la Vida Loca. Colección Debate. v. 9. El Salvador: UCA Editores; 1998.

60. Zaluar A. Violence, argent facile et justice au Brésil: 1980-1995. Revue Internationale des Sciences Sociales 2001; 169:477-84.

61. Collison M. In search of the high life: drugs, crime, masculinities and consumption. Br J Criminol 1996; 36:429.

62. Dubet F. La galere: jeunes en survie. Paris: Points Actuels; 1987.

63. Levi-Strauss C. Las estructuras elementales del parentesco. Buenos Aires: Paidós; 1964.

64. Lacan J. Ecrits. Paris: Seuil; 1976.

65. Briceño-León R, Camardiel A, Ávila O. El derecho a matar en América Latina. In: Briceño-León R, editor. Violencia, sociedad y justicia en América Latina. Buenos Aires: Consejo Latinoamericano de Ciencias Sociales; 2002. p. 383-40.

66. Veckmans R, Venegas R. Marginalidad, incorporación e integración. Santiago de Chile: Centro para el Desarrollo Económico y Social de América Latina; 1966.

67. Desarrollo Económico y Social de América Latina. La marginalidad urbana: origen, proceso y modo. Buenos Aires: Editorial Troquel; 1970.

68. Nun J. Superpoblación relativa, ejercito industrial de reserva y masa marginal. Revista Latinoamericana de Sociología 1969; 2:178-236.

69. Murmis M. Tipos de marginalidad y posición en el proceso productivo. Revista Latinoamericana de Sociología 1969; (2):413-21.

70. Santos M. Geografía y economía urbana en los países subdesarrollados. Barcelona: Oikos-Tau; 1973.

71. Quijano A. El proceso de urbanización en América Latina. Santiago de Chile: Comisión Económi- ca para América Latina y el Caribe; 1996.

72. Quijano A. Dependencia, urbanización y cambio social en Latinoamérica. Lima: Mosca Azul; 1977.

73. Bolivar T. Urbanizadores, constructores y ciudadanos. Rev Mex Sociol 1995; (1):71-87.

74. Bolivar T, Guerrero YM, Rosas I, Ontiveros T, Freitas J. Densificación y vivienda en los barrios caraqueños. Contribución a la determinación de problemas y soluciones. Caracas: Mindur-Conavi; 1994.

75. Bell D. Los portuarios controlados por el racket: la telaraña de la economía y la política en el fin de las ideologías. Madrid: Tecnos; 1964.

76. Messerschmidt J. Masculinities and crime. Lanham: Rowman and Littlefield Publishers; 1993.

77. Jefferson $\mathrm{T}$. Introduction: masculinities, social relations and crime. Br J Criminol 1996; 36:337-47.

78. Spierenburg P. Masculinity, violence and honor: an introduction. In: Spierenburg P, editor. Men and violence: gender, honor and rituals in modern Europe and America. Ohio: The Ohio State University Press; 1998. p. 1-36.

79. Zubillaga V, Briceño-León R. Exclusión, masculinidad y respeto: algunas claves para entender la violencia entre adolescentes en barrios. Nueva Sociedad 2001; 173:34-78.

80. Vidal D. Le respect: catégorie du social, catégorie du politique dans une favela de Recife. Cultures et Conflits 1999; (35):95-124.

81. Nisbett RE, Cohen D. Culture of honor: the psychology of violence in the South. Oxford: Westview Press; 1997.

82. Castillo A. Menores transgresores: en búsqueda de adaptación social. Caracas: Universidad Central de Venezuela; 1997.

83. Marquez P. The street is my home. Stanford: Stanford University Press; 1999.

84. Palmer DS. Drogas y seguridad en el Mercosur. Buenos Aires: Instituto Nacional de Administración Pública; 1998.

85. Velez LF, Espitia VE, Banguero H, Méndez F, Muñoz E, Rotawinsky W, et al. Violencia en Colombia un análisis exploratorio del caso de la ciudad de Cali. Cali: Universidad de Valle/World Bank; 1999.

86. Small Arms Survey. Small Arms Survey 2004: rights at risk. Oxford: Oxford University Press; 2004.

87. Small Arms Survey. Small Arms Survey 2003: development denied. Oxford: Oxford University Press; 2003.

88. Peres-Tourinho MF. Violência por armas de fogo no Brasil. São Paulo: Núcleo de Estudos da Violência, Universidade de São Paulo; 2004.

89. Cruz JM. La victimización por violencia urbana: niveles y factores asociados en ciudades seleccionadas de América Latina y España. Washington DC: Organización Panamericana de la Salud; 1999.

90. Briceño-León R, Camardiel A, Avila O, De Armas E. ¿Quiénes son las víctimas de la violencia en Caracas? Un análisis social del riesgo de la violencia no-fatal. Trib Invest 1998; 5:5-19.

91. Safouan M. La parole ou la Mort. Comment une societe humaine est-elle possible? Paris: Éditions du Seuil; 1993.

92. Freud S. La interpretación de los sueños. Obras completas. Tomo I. Madrid: Biblioteca Nueva; 1973. 
93. Minayo M.C, Souza ER. Violência para todos. Cad Saúde Pública 1993; 9:65-78.

94. Sen A. Health in development. Bull World Health Organ 1999; 77:619-23.

95. Briceño-León R, Piquet L, Cruz JM. O apoio dos cidadãos à ação extrajudicial da policia no Brasil, em El Salvador e na Venezuela". In: Pandolfi DC, Carvalho JM, Carneiro LP, Grynzpan M, organizadores. Cidadania, justiça e violência. Rio de Janeiro: Editora da FGV; 1999. p. 117-27.

96. Cano I. The use of lethal force by police in Rio de Janeiro. Rio de Janeiro: Instituto de Estudos da Religião; 1997.

97. Cruz-Neto O, Minayo MCS. Extermínio: violentação e banalização da vida. Cad Saúde Pública 1994; 10 Suppl 1:199-212.

98. Pinheiro PS. El Crimen, la violencia y la pobreza urbana. In: Seminar on Urban Poverty. Rio de Janeiro: Asociación Latinoamericana de Organizaciones de Promoción/World Bank; 1998.

99. Mateus-Guerrero S. Limpiezas sociales. La guerra a la indigencia. Santa Fe de Bogotá: Ediciones Tiempo de Hoy; 1995.

100. Briceño-León R, Zubillaga V. Violence and globalization in Latin America. Current Sociology 2002; 50:19-37.
101. Tavares-dos-Santos T. The worldization of violence and injustice. Current Sociology 2002; 50: 123-34.

102. Organización Panamericana de la Salud. Repercusiones de la violencia en la salud de las poblaciones Americanas. Washington DC: Organización Panamericana de la Salud; 2003.

103. Population Reference Bureau. Population data sheet. New York: Population Reference Bureau; 2004.

104. Instituto APOYO. La violencia en el Perú: dimensionamiento y políticas de control. Informe preliminar. Lima: Red de Centros de Investigación, Banco Interamericano de Desarrollo; 1997.

105. Lederman D. Crime in Argentina: a preliminary assessment. Washington DC: World Bank; 1999.

106. Centro Latinoamericano y Caribeño de Demografía, División de Población. Transformaciones demográficas en América Latina y el Caribe y consecuencias para las políticas públicas, en panorama social de América Latina. Santiago de Chile: Comisión Económica para América Latina y el Caribe; 2004.

Submitted on 30/May/2005

Approved on 03/Jun/2005 